\title{
Kaomu : Surviving Strategy Group Nobility the Community Structure Buton
}

\author{
La Ode Abdul Munafi, ${ }^{*}$ Mahmud Tang,**Muh. Basir Said,**Tasrifin Tahara** \\ "Graduate Student PhD, Study Program : Science Of Antropology. Hasanuddin University, \\ Makassar, Indonesia \\ ** Faculty of Social and Political Sciences, University of Hasanuddin, Makassar, Indonesia
}

Received 19 January, 2016; Accepted 16 February, 2016 (C) The author(s) 2015. Published with open access at www.questjournals.org

\begin{abstract}
This study aimed to understand the actions of our group in maintaining their traditional legitimacy as the dominant group in the structure of society Buton. Following the dissolution of the Sultanate of Buton 1960, the group was faced with the erosion of legitimacyI traditional status as a result of mobility between the layers in the structure of society. Realizing the potential for changes in social order, they perform strategic steps in order to maintain the legitimacy to their late-kaomu, through the preservation of reproductive indigenous discourse, educational institutions, political parties, and the revitalization of the Sultanate of Buton become customary institutions. Through various strategies that constructed this arena, the group kaomu trying reestablish their traditional legitimacy as the dominant group in the structure of society.
\end{abstract}

Keywords:- Social Stratification, Nobility, and Power.

\section{INTRODUCTION}

Каоти are a group designation nobility in society stratification system Buton (Zahari, 1977; Rudyansjah, 2009). During the era of the empire, they become the dominant group in the structure of society. The dissolution of the Sultanate of Buton 1960 presenting any implications for the weakening of the traditional domination kaоти group. They not only lose access to power in government institutions, but a privilege and prestige that the justification of their traditional status has experienced crushing. The implementation of land reform policy in 1960 implicated in the loss of their authority to control land tenure in the former Sultanate of Buton. Removal of some religious practices in government institutions by means of religion, because it is seen as the traditional Islamic heritage, they weaken the symbolic power in the structure of society (Tahara, 2014). At the same time, they are also confronted with the emergence of the status of "honor" in the community with reference to the achievements of the achievements of actors, such as achievements in education, positions in politics and government, as well as success in the economic field. Not only that, the bottom layer group in a traditional structure, with the achievements of exemplary achievement in the community, helped construct a social identity as kаоти, through the use of traditional status symbols kaоти. This practice then led grouping kаоти "new" where status-kaomu late tend to be constructed based on the principle prestatif. Realizing the potential change of social order, the group kaomu perform strategic steps in order to maintain the legitimacy of their traditional status as the dominant group in society.

A number of authors such as Ligtvoet (1878), Berg (1937; 1939) and Schoorl (2003) saw the stratification system Buton society as a form of social arrangement in three Standen. Zahari (1977), Jonah (1995), Yamaguchi (2001), Palmer (2004), and Zuhdi (2010) sees it as part of the ideology of power. Publication they do not encapsulate the dynamics in the structure of society. Dynamics of community structure presented in the study Rudyansjah (2009) and Tahara (2014). However, the study did not survive the group summarizes actions каоти, through the adaptation of the state institutions in the modern era, as a medium for maintaining the status quo of their legitimacy as the dominant group. Therefore, this study to be a "starting point" to understand the construction domination of nobility that is still produced in line with the transformation of society Buton.

\footnotetext{
*Corresponding Author: La Ode Abdul Munafi,*

"Graduate Student PhD, Study Program : Science Of Antropology. Hasanuddin University,

$1 \mid$ Page Makassar, Indonesia
} 


\section{RESEARCH METHODS}

This anthropological study using qualitative methods. Data collected through interviews, observation and research documents. Setting starting from Baubau City. As a former center of the Sultanate of Buton, City Baubau an arena of interaction people kaomu, walaka, and Papara; three social groups in traditional stratification system Buton society. Because of the level of mobility of the subject, the research setting extends to several areas outside the City Baubau, namely Buton, Wakatobi, Kendari and Makassar.

The subjects are people who have traditionally come from the group kaomu are divided into several categories, namely : (i) those who have been through the empire, (ii) officials institutional means of religion, (iii) the management Indigenous Institute Sultanate of Buton, (iv ) politicians and bureaucrats, (v) employers and (6) the younger generation kaomu.

The data were analyzed descriptively-ethnography, which describe the research subjects and the way they act and speak (Endraswara, 2012: 215). Analysis using an interactive model, include; (i) data reduction, (ii) exposure data, and (iii) conclusion, through the delineation and verification (Miles and Huberman, 1992). The analysis process is done through the phasing model of ethnography Spradley (1997), including domain analysis, taxonomy, componential and cultural themes.

\section{Society stratification system Buton}

\section{RESULTS AND DISCUSSION}

Traditionally, people Buton distinguished four social layers, namely, kaomu, walaka, Papara, and Batua (Yunus, 1995, Schoorl, 2003; Rudyansjah 2009, Tahara, 2014). In the system of stratification, kaomu viewed as the top layer, or among those noble (Anceaux, 1987: 67), or the nobility (Schoorl, 2003: 213), or the nobility according to common designation (Zahari, 1977; Yunus, 1995 ; Rudyansjah 2009; Tahara, 2014). Walaka an intermediate layer, also called lower nobility (Rudyansjah 2009), Papara as the lower layer, and the layer Batua as slaves. In the process, Batua be categorized Papara layer (Schoorl, 2003: 217) .Schoorl (2003: 213) calls this stratification system of rank, which refers to a position or rank in the governance structure. Yunus (1995: 24) calls for political reasons and power as the foundation of stratification system, ie to differentiate groups who should and should not occupy high positions in the empire row. Based on the principle of position, kaomu and walaka have the authority to occupy certain positions in the center of the empire. Meanwhile, Papara entitled to administrative positions at the level of Kadie (village) roomates occupied. Yamaguchi (2001) calls Buton stratification of society as a system based on differences in the function and role in the empire. Kaomu is a group of people than the sultan were selected, and form a group of executives, walaka as a community group that selects the sultan, and formed a legislative group. Meanwhile, Papara forming productive groups. In another perspective, Rudyansyah (2009) mentions Kamia (the origin or lineage of a person) as the cornerstone stratification. Based Kamia, kaomu group descended from a line according to the father of King Wa Kaa Kaa (King of Button. I). Каоти group was divided into three categories relative, ie kaomu tanayilandu, kaomu tapitapi, and kaоти kumbewaha (Zahari, 1977). All three are commonly called kamborumboru talupalena, which means "three's pole" (Anceaux, 1987). Walaka group descended from a line according to the father of the founders of the Wolio Community, the forerunner to the center of the kingdom of Buton. They are called mia patamiana (four figures). Meanwhile, Papara is resident Kadie (village), originating from tribes that inhabited before the establishment of the kingdom of Buton. Papara divided into three sub-groups, namely, Paparaparaka, derived from community groups who surrendered to the ruler of the kingdom of Buton, Paparatalubhirana, come from prisoners of war, and Papara-kantinale, namely Papara were downgraded due to violations of customs (Zahari, 1977: 87). In the system of stratification, two subgroups Papara latter categorized as Batua (slave) (Yunus, 1995: 24; Rudyansjah, 2009: 51). In the process, Batua then be maradhika (independent), and aligned with Papara. Kaоmu, walaka, and Papara, are the three social groups in traditional stratification system, which is still found in Buton society.

\section{We Survived Action Group}

Throughout the Sultanate of Buton, the group you have privileges in power, privilege, and prestige. Status as kaomu have put them into the dominant group in the structure of society. Over time, they are then faced with the erosion of legitimacy virtue of social status. Equal rights and status as citizens, which necessitates Achieved (status attainment), as an indicator of honor in the new era (nature to the Indonesian-ness), becoming a threat to the legitimacy of their traditional status. In the following essay presented some patterns of action that are constructed kaоmu groups as a strategy to maintain the legitimacy of their status quo as the dominant group in the structure of society. 


\section{Surviving Through Indigenous Institution}

Custom wedding procession in Buton, become an arena for kaomu group showed its dominance. Their dominance was reflected by the level of dowry (popolo). Mahar kaomu higher than Walaka and Papara, because customarily they regarded as a descendant of the kings of Buton. The same is reflected by the difference Pasali or level "attendance money" (Anceaux, 1987 : 117) which is given to a person in a traditional procession. Different levels of dowry and Pasali a kaоmu with social layers underneath reflects the height of their traditional status in the structure of society.

Your group dominance is also reflected through recruitment patterns apparatus means religion (traditional religious institution based in the Great Mosque of Sultan Buton). In this institution there is a hierarchy of positions, the personnel recruited by the social layers of society Buton. Rows of high office, ranging from Hatib, priests, until lakina religion, customarily only be recruited from the group kaоти. Legitimacy is based custom views that they, as well as the descendants of the kings of Buton, also was a descendant of Sayid Abdul Wahid, mubaliq disseminator of Islam in Buton, who is seen as a descendant of the Prophet. Therefore, the group kaоти obtain justification as "enforcers religion" as well as heir of the Prophet. Meanwhile, the portion walaka obtain positions moji (Bilal), as an intermediate position, and the position tungguna Papara double (drum beater), a low position in the means of religion.

The main strength of the legitimacy of your very survival depends on the conservation of the indigenous community who support the stratification system Buton. When customs, as supporters of stratification were not recognized or abandoned community, then they too will be lost legitimacy. Realizing this, the indigenous elite kаоти always reproduce the discourse on the need to cherish and preserve tradition. A traditional leaders stated that kаоти is someone who was born in status as kaоти, since it has been established in the customs. Who changed the traditional means changing societal foundations that have been laid ancestors, and the like that can be shot katunda (curse). In his essay on the strategy of domination, Bourdieu (2012) states, that dominance can be done is not visible, such as through knowledge or discourse. The importance of the preservation of indigenous elite discourse of indigenous kоaти always be interpreted as a strategy to maintain their dominance in the structure of society.

\section{Surviving through Educational Institutions}

Buton progress in education can not be separated from the role of the people kaomu. In the middle of difficulty of the sons of Buton continue their education to higher education, in early 1982, a large family of La Ode Manarfa (son of the last sultan of Buton) founded a university in Baubau, which is named after the University Dayanu Ikhsanuddin (Unidayan). Establishment of this university initiated the establishment of the Foundation Trustees Unidayan, which consists of a large family of La Ode Manarfa. Unidayan operation since 1983, and obtained permission 1986sesuai registered in SK. Minister of Education and Culture No. 0533 / O / 1986 dated August 5, 1986. Until this study lasted Unidayan has 7 faculties, 15 Prodi S1 and S2 2 study programs, the number of students enrolled 9,000 people, 400 faculty and administrative staff, as well as tens of thousands of alumni. At the beginning of operations in 1983, rector Unidayan held La Ode Malim (La Ode Manarfa-in-law), and La Ode Manarfa served as chairman of the foundation. After La Ode Malim died in 1985, the position of rector held La Ode Manarfa, and the post of chairman of the foundation handed over to his daughter, Wa Ode Maasra Manarfa, who served until now. In 2003, La Ode Manarfa replaced law (Abdul Madjid Sarah) as the third chancellor, and the latter replaced La Ode Muhammad Arsal (La Ode Manarfa nephew) as the fourth rector. Currently, rector Unidayan held La Ode Muhammad Sjamsul Qamar (La Ode Manarfa-law) who are also husband Wa Ode Maasra Manarfa (chairman of the foundation Unidayan). Institution of higher education founded La Ode Manarfa large families, besides making Baubau has a role as a center of education in the area of Buton Kingdom also has put large families La Ode Manarfa as a respected family and has extensive influence in society Buton. Action big family La Ode Manarfa establish institutions of higher education can be interpreted as an act of power. Through ownership over Unidayan, they gain legitimacy as a family prominent in today's society Buton.

\section{Surviving Through Political Parties}

1955 election was the first election held after Indonesia's independence. In status as autonomous regions, this election event Also thud of earth Buton Sultanate. Large families last sultan of Buton La Ode Muhammad Falihi, initiated La Ode Manarfa (the eldest son of the sultan), affiliated to Masjumi, while some kaomu others, initiated La Ode Hadi (cousin La Ode Manarfa) and La Ode Halim, affiliated to the PNI. Kaomu plunging people in the arena of political parties, ushering Masjumi and PNI became the winner of the first and second elections 1955 in Buton. Victory two parties led by figures in Buton kaоти then deliver La Ode Manarfa served as Regent of Southeast Sulawesi (1959-1960), La Ode Halim became regent Buton (1960-1965), La Ode Arsyad be the Chairman of the Parliament of Buton, and La Ode Hadi became Governor of Southeast Sulawesi province (1965-1967). Year 1967-1971, La Ode Manarfa also became Chairman of the Parliament-GR 
Southeast Sulawesi Province. Since the 1971-1987 elections, he even became a member of Parliament from Golkar.

In the reform era, large families La Ode Manarfa affiliated to the Crescent Star Party (PBB). Under its auspices, the parties are imaged as the transformation of this Masjumi Party, won the 2004 legislative election in Ode Maasra Baubau. Wa City (La Ode Manarfa daughter) and then served as Chairman of the Parliament Baubau period 2004-2009. Through the Crescent Star Party anyway, son of La Ode Manarfa, namely La Ode Halaka Manarfa, paired with Amirul Tamim, won the election Baubau City in 2008, and the election in 2013, the daughter of La Ode Manarfa, namely Wa Ode Maasra Manarfa, paired with US Thamrin, also won the election in Baubau City.

Narrative above shows that the political parties have become reproductive tract power kaomu group. Their involvement in political parties, in addition to the interests of the public, can also be interpreted as a strategy to maintain the legitimacy of the status quo as the dominant group in the structure of society.

\section{Bring back the "Sultanate of Buton"}

The dissolution of the Sultanate of Buton 1960 apparently not thoroughly followed by the dissolution of the local institutions at the level Kadie (Sara Kadie), which traditionally run the local government affairs Kadie, domicile Papara groups. Sara Kadie although nowadays no longer perform tasks of local government, but these institutions still have legitimacy among the group Papara. Sara Kadie in the shade, holding indigenous life Papara group lasted until now.

The dissolution of the empire led to your group, and also walaka increasingly do not have access to stints coaching and supervision of the ex Kadie as they played during last. Over time line, community loyalty Kadie (Papara groups) also, against kaomu and walaka, more eroded. Realizing this, the figures kaomu and walaka then initiated the founding of the Institute of Traditional Buton Sultanate as a "big umbrella" organization of indigenous life throughout the territory of the former Sultanate of Buton. On 12 April 2012, figures kaomu and walaka, declare Indigenous Institute Buton Sultanate attended traditional leaders of a number of districts / cities in the coverage area of the former Sultanate of Buton. For the first time, the Institute of Traditional Sultanate of Buton led La Ode Djafar, which Sultan Buton confirmed as 39th on July 27, 2012. At the time of Baubau host Kraton Nusantara VIII Festival, September 1-4, 2012, the traditional institution that is the representation of the Sultanate of Buton in cultural festival the national level. Now, the Sultanate of Buton Indigenous organizations led La Ode Izzat Manarfa as Sultan Buton 40th. Bring back sultan through container Indigenous Institute Sultanate of Buton, can be interpreted as a strategy group kaomu to revive memories of the empire period, in order to become a citizen reminder, that once there was a period in which the empire had triumphed and put the values of wisdom for the people of Buton. The phenomenon of "return of the Sultan" which contained these traditional institutions, can also be interpreted as a strategy group kaomu to strengthen their negotiating position and the structure of contemporary society. Through Indigenous Institute Sultanate of Buton, kaomu group, which traditionally has a cultural symbol of power, tried to reestablish their traditional legitimacy as the dominant group in the structure of society.

\section{CONCLUSION}

As the dominant group in the traditional structure, the group you are trying to retain power, privilege, and prestige in a lifestyle that has been internalized within them. Realizing the potential change of social order after the dissolution of the Sultanate of Buton, kaоmu group perform strategic steps in order to maintain the legitimacy of their status quo as the dominant group. Strategic measures referred constructed through discourse reproduction and preservation of indigenous awards, initiated the establishment of educational institutions, were actively involved in the arena of political parties, as well as revitalize the sultanate became Indigenous Institute institutions Buton Sultanate. Through various strategies that constructed this modern social arena, the group kaomu trying reestablish their traditional legitimacy as the dominant group in society Buton.

\section{REFERENCES}

[1]. Anceaux, J.C., 1987. Wolio Dictionary;Wolio-English-Indonesian.KITLV, Foris Publications Holland. Dordrecht Holland/Providence-USA.

[2]. Berg, E.J. van Den, 1937. "De viering van den raraja hadji in de Kota Wolio (Boeton)". Tijd., LXXVII, 469-528.

[3]. - -------, 1939. "Adatgebruiken in verband met de sultansinstallatie in Boetoen". Tijd. LXXIX, 469-528.

[4]. Bourdieu, Pierre, 2012.Arena Produksi Kultural; Sebuah Kajian Sosiologi Budaya, oleh Yudi Santoso (penerjemah).Yogyakarta. Kreasi Wacana.

[5]. Endraswara, Suwardi, 2003. Metode Penelitian Kebudayaan. Yogyakarta. Gadjah Mada University Press.

[6]. Ligtvoet, A., 1878. "Beshrijving en Geshiedenis van Boetoen." Bijd., XXVI.

[7]. Miles, Matthew dan A. Huberman, 1992.Analisis Data Kualitatif.Jakarta.U.I.Press.

[8]. Palmer, Blair, 2004. "Migrasi dan Identitas; Perantau Buton yang Kembalike Buton Setelah Konflik Maluku 19992012".Artikel.Jurnal Antropologi Indoesia Th. XXVIII, No. 74.

[9]. Rudyansyah, Tony, 2009. Kekuasaan, Sejarah, dan Tindakan; Sebuah Kajian Tentang Lanskap Budaya. Jakarta: Rajawali Pers.

[10]. Schoorl, Pim (JW), 2003.Masyarakat, Sejarah, dan Budaya Buton. Jakarta. Penerbit Jambatan-Perwakilan KITLV. 
[11]. Spradley, James P., 1997. Metode Etnografi. Yogyakarta. Tiara Wacana.

[12]. Tahara, Tasrifin, 2014. Melawan Stereotipe; Etnografi, Reprodukasi Identitas, dan Dinamika Masyarakat Katobengke Buton yang Terabaikan. Jakarta. Kepustakaan Populer Gramedia.

[13]. Yamaguchi, Hiroko, 2001. Interim Report, "A Study on Cultural Representations of The Historical Past in Buton Society, Southeast Sulawesi, Department of Anthropology Hitosubashi University Tokyo Japan.

[14]. Yunus, Abdul Rahim, 1995.Posisi Tasawuf Dalam Sistem Kekuasaan di Kesultanan Buton Pada Abad ke-19, Seri INIS; Jilid 24. Jakarta: Indonesian-Netherlands Cooperation in Islamic Studies.

[15]. Zahari, A.M. Mulku, 1977. Sejarah dan Adat Fiy Darul Butuni.Jakarta. Depdikbud.

[16]. Zuhdi, Susanto.2010. Labu Rope Labu Wana; Sejarah Buton yang Terabaikan. Jakarta. Rajawali Pers. 